\title{
An Investigation into Infection Prevention and Control Practices among Close Contacts of COVID-19 Positive Cases Identified during Trace Test and Quarantine Activities at District Quetta (Unmatched Case-Control Study)
}

\author{
Muhammad Arif ${ }^{1}$, Abid Saeed ${ }^{1}$, Muhammad Abdullah ${ }^{2}$, Ambreen Chaudhary ${ }^{3}$, Zakir Hussain ${ }^{3}$ \\ Mirza Zeeshan Iqbal Baig ${ }^{3}$, Zubair Ahmed Khoso', Mir Abdul Qadir ${ }^{4}$, Sheikh Ahmed ${ }^{1}$, \\ Saher Sultan', Zahra Gauhar6, Ayesha Babar Kawish7, Ehsan Larik ${ }^{1}$ \\ ${ }^{1}$ Department of Health, FELTP Pakistan, Quetta, Pakistan \\ ${ }^{2}$ Department of Health, WHO, Quetta, Pakistan \\ ${ }^{3}$ Department of Health, FELTP Pakistan, Islamabad, Pakistan \\ ${ }^{4}$ Department of Health, IPH Quetta, Quetta, Pakistan \\ ${ }^{5}$ Department of Community \& Preventive Dentistry, AMC, NUMS, Rawalpindi, Pakistan \\ ${ }^{6}$ Department of Health, BMC, Quetta, Pakistan \\ ${ }^{7}$ Department of Health, PIO, Rawalpindi, Pakistan \\ Email: arifnasr@gmail.com, abidsaeed25@gmail.com, abdullahnasar59@gmail.com, ambr.chaudhry@gmail.com, \\ dratish05@gmail.com,z.iqbalbaig@gmail.com,drzubairkhoso@gmail.com,drmirqadir@gmail.com, \\ sheikhzahid2001@gmail.com, sehr.sultan@hotmail.com, hasansultan2@yahoo.com, aykawish@gmail.com, \\ ehsanlarik@gmail.com
}

How to cite this paper: Arif, M., Saeed, A. Abdullah, M., Chaudhary, A., Hussain, Z., Baig, M.Z.I., Khoso, Z.A., Qadir, M.A., Ahmed, S., Sultan, S., Gauhar, Z., Kawish, A.B. and Larik, E. (2021) An Investigation into Infection Prevention and Control Practices among Close Contacts of COVID-19 Positive Cases Identified during Trace Test and Quarantine Activities at District Quetta (Unmatched Case-Control Study). Open Journal of Epidemiology, 11, 360-370.

https://doi.org/10.4236/ojepi.2021.114030

Received: August 28, 2021 Accepted: October 10, 2021 Published: October 13, 2021

\begin{abstract}
The second wave of COVID-19 pandemic has started globally, right now 220 countries are infected and a total of 71,351,695 confirmed cases and 1,612,372 deaths due to COVID-19 have been reported. Infection Prevention and Control (IPC) measures for COVID-19 all have proved vital in decreasing the transmission rates among the communities. Methodology: Unmatched CaseControl Study was conducted where cases were defined as "every PCR positive contact (symptomatic or asymptomatic) for any index case" similarly controls were defined as "every PCR negative contact (symptomatic or asymptomatic) for any index case who was home quarantined for 14 days based on suspicion by PDSRU team". A simple random technique was used and 300 individuals were made part of this study. Results: The major findings of this study shows that PCR positive contacts poorly adopted certain COVID-19 IPC measures of interest in their daily life hence got infected. The odds for all the
\end{abstract}


Copyright $\odot 2021$ by author(s) and Scientific Research Publishing Inc. This work is licensed under the Creative Commons Attribution International License (CC BY 4.0).

http://creativecommons.org/licenses/by/4.0/ variables of interest were found to be statistically significant among cases as compared to controls like the odds for knowingly and intentionally contacted with a COVID-19 positive case was 13.7 times more among the PCR positive contacts as compare to PCR negative contacts $(p=0.00$, C.I $=7.62-24.90)$, similarly, the odds of being a family member of the index COVID-19 case was 7.07 times more among the PCR positive contacts as compared to the PCR negative contacts $(p=0.00, C . I=3.25-15.86)$. Conclusion: Before the development and availability of a vaccine, the only tools that can help prevent the spread of COVID-19 are IPC measures.

\section{Keywords}

COVID-19, IPC Measures, Contact, PCR, PDSRU

\section{Introduction}

Globally, the second wave of the COVID-19 pandemic has begun; currently, 220 countries are afflicted, with a total of 71,351,695 confirmed cases and 1,612,372 deaths attributable to COVID-191. As of today, i.e. $16^{\text {th }}$ December 2020, a total of 11,430,955 new COVID-19 confirmed cases have been reported across the southeast Asia [1]. These cases are showing an increasing trend in all the Asian countries including Pakistan [1]. Across Pakistan, till date, 440,787 new confirmed COVID-19 cases have been reported showing a doubling time of 10.63 days (95\% C.I 9.68 - 11.8), while a total of 8832 new deaths have been reported across Pakistan making the double-time for death as 11.11 days (95\% C.I $4.04-14.86$ ) [2]. Before the development and availability of a vaccine, the only tools that can help prevent the spread of COVID-19 are IPC measures, violating them can result in a quick spread across the population [3] [4].

Provincial Disease Surveillance \& Response Unit (PDSRU) has always been the first responder to each outbreak across Balochistan province and currently it is a focal point for Trace Test and Quarantine (TTQ) strategy across Balochistan. PDSRU is run by trained field epidemiologists trained by field epidemiology, and laboratory training program in Pakistan. So PDSRU responded to the COVID-19 second wave and took an active part in implementing the Trace Test and Quarantine (TTQ) activities across Balochistan province including District Quetta and has recorded detailed epidemiological reports for every case in the field as ever.

\section{Literature Review}

Infection Prevention and Control (IPC) measures for COVID-19 like keeping 6 feet social distancing, wearing face mask, avoiding gathering and regularly washing hands were all proved vitals in decreasing the transmission rates among the communities [5] [6] [7] [8] [9]. In another study done by Hsiang, S. and others observed that the ongoing anti-contagion policies have already substantially re- 
duced the number of COVID-19 infections observed in the world today according to their calculations all policies of SOPs and IPC measured when properly implemented slowed the average growth rate of infections by -0.252 per day (SE $=0.045,164 \mathrm{p}<0.001)$ in China, $-0.248(\mathrm{SE}=0.089, \mathrm{p}<0.01)$ in South Korea, $-0.24(\mathrm{SE}=0.068, \mathrm{p}<0.001)$ in 165 Italy, $-0.355(\mathrm{SE}=0.063, \mathrm{p}<0.001)$ in Iran, $-0.123(\mathrm{SE}=0.019, \mathrm{p}<0.001)$ in France and $-0.084166(\mathrm{SE}=0.03, \mathrm{p}<0.01)$ in the US [10].

In another study done by Lai, S. and the others where they predicted the infection rates and quantified the impact of various Non-Pharmacological Interventions (NPI) according their calculations Without NPIs, their model predicted the number of cases of COVID-19 to increase rapidly across China, with a 51-fold (IQR 33 - 71) increase in Wuhan, a 92-fold (58 - 133) increase in other cities in Hubei province and a 125 -fold $(77-180)$ increase in other provinces by $29^{\text {th }}$ February 2020. However, the apparent effectiveness of different interventions varied. Nevertheless, if intercity travel restrictions had been implemented, cities and provinces outside of Wuhan would have not received more cases from $\mathrm{Wu}$ han, and the affected geographical range would not have expanded to the remote western areas of China. In general, they estimated that the early detection and isolation of cases quickly and substantially adopting IPC measure more infections were controlled like contact reduction and social distancing measures across the country. However, without the contact reduction intervention, in the longer term the epidemics would have increased exponentially across regions. Therefore, collective NPIs would bring about the strongest and most rapid effect on containment of the COVID-19 outbreak, with an interval of about one week between the introduction of NPIs and the peak of the epidemic [11].

In another study by Flaxman, S. and the others showed that major non-pharmaceutical interventions-and lockdowns in particular-have had a large effect on reducing transmission in Europeans. Continued intervention should be considered to keep transmission of SARS-CoV-2 under control [12] [13].

The waves of COVID-19 will continue to repeat, like wise every sector, profession and every human conduct will always remain prone to it till the production and availability of vaccine to the common people and almost $60 \%$ herd immunity is achieved [12] [13]. In these crisis situations trends towards new normal life must be focused and IPC measures should be made part of routine [14].

\section{Operational Definition of "Contact"}

Contact was defined as a person who have had contact, without effective protection regardless of duration of exposure, with 1 or more persons with suspected or confirmed COVID-19 any time starting 2 days before onset of symptoms in persons with a suspected or confirmed case, or 2 days before sampling for laboratory testing of asymptomatic infected persons [10].

Problem Statement

COVID-19 is a highly contagious disease till the development and availability of COVID-19 vaccine the waves of this pandemic will continue to occur repeat- 
edly hence each wave could potentially reach to new heights of infectivity and mortality.

\section{Rationale}

So far no published literature has studied the odds for COVID-19 Infection Prevention and Control (IPC) measures among the common masses of developing countries like Pakistan where literacy rates are low poverty and population is high as a result huge number of family members shares a single room for living.

\section{Objectives}

- To assess the odds for certain anti-COVID-19 IPC measures among the Contacts of an index COVID-19 case traced by Provincial Disease Surveillance \& Response Unit Quetta.

- To provide evidence based recommendations for risk communication to the local context via media cell of the Health department of Balochistan so that certain COVID-19 IPC measures are adopted and focused by every resident of Balochistan in their daily life activities till the availability of anti-COVID-19 vaccine.

\section{Methodology}

\section{Sample Size \& Sampling technique}

PDSRU Quetta's Field epidemiologist team recorded detailed epidemiological reports of 600 COVID-19 contacts from during the trace test and quarantine field activities form $1^{\text {st }}$ October till $30^{\text {th }}$ October 2020 in district Quetta, from this data a sample of 300 individuals was selected for this study using Simple random sampling technique. Using the following formula of sample size where C.I of 95\%, 0.5 Population proportion (p), 0.04 Margin of error (e), 600 Population size of the total contacts traced during the field activities of TTQ by PDSRU Field epidemiologist team from $1^{\text {st }}$ October till $30^{\text {th }}$ October 2020, 0.025 alpha divided by 2 and a $\mathrm{z}$-score of 1.96 values were used for the calculation of sample size of 300 .

$$
\frac{\frac{Z^{2} \cdot p(1-p)}{e^{2}}}{1+\left\{\frac{Z^{2} \cdot p(1-p)}{e^{2} N}\right\}}
$$

\section{Study Design}

Considering different exposure rates and pandemic situation an Unmatched Case-Control Study was conducted where cases were defined as "every PCR positive contact (symptomatic or asymptomatic) for any index case" similarly controls were defined as "every PCR negative contact (symptomatic or asymptomatic) for any index case who was home quarantined for 14 days based on suspicion by PDSRU team. A set ratio of 1:2 for cases and controls respectively was used for this study.

\section{Data Collection Tool}

An interview using structured questioner was conducted with every individual 
during data collection.

\section{Analysis Plan}

Epi-info software was used; descriptive statistics for age, sex, educations status, blood groups, co-morbidities, BCG \& seasonal flue vaccination status of the study participants were summarized using frequency tables, while $2 \times 2$ contingency table was used for the calculation odds ratios.

\section{Results}

\section{Socio-Demographic Characteristics of Respondents}

Total 300 contacts were included in this study and their age distribution was as 195 respondents (65\%) were in age category ranging from 1 - 35 years, 101 (34\%) were in range of $>35$ years. Similarly, 100 (33\%) of the study participants were found to be COVID-19 PCR positive and were considered as cases while 200 (67\%) were found to be COVID-19 PCR negative and were taken as controls.

Gender distribution of the participants showed that 197 (66\%) individuals were male while 103 (34\%) were females.

For ethnicity of respondents, 125 (42\%) were Pashtons, 95 (32\%) were Baloch, 55 (18.3\%) were Brahvi, 15 (05\%) were Punjabi and 10 (3.3\%) respondent were from Hazara ethnic group. Some of the other socio demographic characteristics of the participants are summarized as in Table 1.

\section{Inferential Statistics}

The following table summarizes the major findings of this study which are almost in line with the set hypothesis; this study is clearly showing that the odds of various COVID-19 infection prevention and control (IPC) measures studied among COVID-19 PCR positive contacts (cases) and COVID-19 PCR negative contacts (controls) were found to be significant as shown in Table 2:

As shown in Table 2, the odds for knowingly and intentionally contacted with a COVID-19 positive case was 13.7 times more among the PCR positive contacts as compare to PCR negative contacts ( $p=0.00$,C.I $=7.62-24.90)$, similarly the odds of being a Family member of the index COVID-19 case was 7.07 times more among the PCR positive contacts as compare to the PCR negative contacts $(\mathrm{p}=0.00$,C.I $=3.25-15.86)$, also the odds for knowingly and intentionally received an object handed over by a COVID-19 positive case was 6.64 times more among the PCR positive contacts as compare to PCR negative contacts ( $\mathrm{p}=$ 0.00 ,C.I $=2.61-15.98$ ), whereas the odds for touched the same surface/surfaces after it was touched by the index case was 6.15 times more among the PCR positive contact as compare to PCR negative contacts $(p=0.00$,C.I $=3.62-10.43)$, more over the odds for not doing regular Hand washing was 22.24 times more among the PCR positive contacts as compare to the PCR negative contacts ( $\mathrm{p}=$ 00.00 ,C.I $=11.79-41.94$ ), while the odds for knowingly and intentionally did not follow the government SOPs of social distancing during encounter with a positive symptomatic case was 5.58 times more among the PCR positive contacts 
as compare to the PCR negative contacts $(\mathrm{p}=00.00$, C.I $=2.01-16.85)$, also the odds for knowingly and intentionally did not follow the government SOPs of social distancing during sharing of bedroom and toilet with

Table 1. Socio-demographic characteristics of the study participants.

\begin{tabular}{|c|c|c|c|c|c|c|}
\hline S. NO & $\begin{array}{l}\text { Socio-demographic } \\
\text { characteristics of the } \\
\text { study participants }\end{array}$ & Sub-set & $\begin{array}{c}\text { Percentages } \\
(\%)\end{array}$ & $\begin{array}{l}\text { Number } \\
\text { (n) }\end{array}$ & $\begin{array}{l}\text { COVID-19 PCR } \\
\text { +ve contacts } \\
\text { visited by } \\
\text { PDSRU team } \\
\text { (cases) }\end{array}$ & $\begin{array}{l}\text { COVID-19 PCR } \\
\text {-ve contacts } \\
\text { visited by PDSRU } \\
\text { team (cases) }\end{array}$ \\
\hline \multirow{7}{*}{1} & \multirow{7}{*}{ Qualification } & Un-educated & $49 \%$ & 39 & 13 & 26 \\
\hline & & Primary & $9 \%$ & 45 & 15 & 30 \\
\hline & & Metric & $20 \%$ & 27 & 9 & 18 \\
\hline & & Intermediate & $17 \%$ & 120 & 40 & 80 \\
\hline & & Graduation & $3 \%$ & 39 & 13 & 26 \\
\hline & & Masters & $2 \%$ & 30 & 10 & 20 \\
\hline & & Phd & $0 \%$ & 0 & 0 & 0 \\
\hline \multirow{6}{*}{2} & \multirow{6}{*}{ Co-morbidities } & No comorbidity & $90 \%$ & 270 & 90 & 180 \\
\hline & & $\mathrm{DM}$ & $02 \%$ & 6 & 2 & 4 \\
\hline & & Asthma & $04 \%$ & 9 & 3 & 6 \\
\hline & & $\mathrm{HTN}$ & $04 \%$ & 12 & 4 & 8 \\
\hline & & Hepatitis & $02 \%$ & 6 & 2 & 4 \\
\hline & & Ovarian CA & $00 \%$ & 0 & 0 & 0 \\
\hline \multirow{2}{*}{3} & \multirow{2}{*}{ Occupation } & Health care providers & $20 \%$ & 60 & 20 & 40 \\
\hline & & Others & $80 \%$ & 240 & 80 & 160 \\
\hline \multirow{2}{*}{4} & \multirow{2}{*}{$\begin{array}{l}\text { BCG vaccination } \\
\text { status }\end{array}$} & BCG vaccination, no & $63 \%$ & 189 & 63 & 126 \\
\hline & & BCG vaccination, yes & $37 \%$ & 111 & 37 & 74 \\
\hline \multirow{2}{*}{5} & \multirow{2}{*}{$\begin{array}{c}\text { Seasonal flu } \\
\text { vaccination status }\end{array}$} & Seasonal flu vaccination, yes & $7 \%$ & 21 & 7 & 14 \\
\hline & & Seasonal Flu vaccination, no & $93 \%$ & 279 & 93 & 186 \\
\hline \multirow{9}{*}{6} & \multirow{9}{*}{$\begin{array}{l}\text { Blood groups of the } \\
\text { study participants }\end{array}$} & $\mathrm{A}+$ & $7.00 \%$ & 21 & 7 & 14 \\
\hline & & $\mathrm{A}^{-}$ & $4.00 \%$ & 12 & 4 & 8 \\
\hline & & $\mathrm{B}+$ & $27.00 \%$ & 81 & 27 & 54 \\
\hline & & $\mathrm{B}^{-}$ & $3.00 \%$ & 9 & 3 & 6 \\
\hline & & $\mathrm{AB}+$ & $2.00 \%$ & 6 & 2 & 4 \\
\hline & & $\mathrm{AB}^{-}$ & $1.00 \%$ & 3 & 1 & 2 \\
\hline & & $\mathrm{O}+$ & $1.00 \%$ & 3 & 1 & 2 \\
\hline & & $\mathrm{O}^{-}$ & $1.00 \%$ & 3 & 1 & 2 \\
\hline & & unkown & $54.00 \%$ & 162 & 54 & 108 \\
\hline
\end{tabular}


Table 2. Odds ratios for the various Infection prevention and control measures studied in this study.

\begin{tabular}{|c|c|c|c|c|c|c|}
\hline $\begin{array}{c}\text { Most important } \\
\text { COVID-19 IPC measures voilations }\end{array}$ & Responses & $\begin{array}{l}\text { COVID-19 PCR } \\
\text { positive contacts } \\
\text { visited by the } \\
\text { PDSRU team } \\
(\text { Case }=100)\end{array}$ & $\begin{array}{l}\text { COVID-19 PCR } \\
\text { negative contacts } \\
\text { visited by the } \\
\text { PDSRU team } \\
(\text { Case }=200)\end{array}$ & OR & C.I & P-value \\
\hline $\begin{array}{l}\text { Deliberate contact with a } \\
\text { COVID-19 positive case }\end{array}$ & Yes & 80 & 45 & 13.7 & $7.62-24.90$ & 0.00 \\
\hline Family member of the index COVID-19 case & Yes & 25 & 9 & 7.07 & $3.25-15.86$ & 0.00 \\
\hline $\begin{array}{l}\text { Deliberately received an object handed over by a } \\
\text { COVID-19 Positive case }\end{array}$ & Yes & 19 & 7 & 6.46 & $2.61-15.98$ & 0.00 \\
\hline $\begin{array}{l}\text { Touched the same surface/surfaces after it was } \\
\text { touched by the index case }\end{array}$ & Yes & 70 & 55 & 6.15 & $3.62-10.43$ & 0.00 \\
\hline Not doing regular hand washing & Yes & 83 & 36 & 22.24 & $11.79-41.94$ & 0.00 \\
\hline $\begin{array}{l}\text { Deliberately not following the Govt SOPs of social } \\
\text { distancing during encounter with a poisitive } \\
\text { symptomatic case }\end{array}$ & Yes & 13 & 5 & 5.58 & $2.01-16.85$ & 0.00 \\
\hline $\begin{array}{l}\text { Deliberately not following the Govt SOPs of social } \\
\text { distancing during sharing of bedroom and toilet } \\
\text { with poisitive symptomatica case }\end{array}$ & Yes & 23 & 10 & 5.67 & $2.58-12.48$ & 0.00 \\
\hline $\begin{array}{l}\text { Used the same vehicle after it was used by the } \\
\text { COVID-19 index case }\end{array}$ & Yes & 63 & 16 & 19.58 & $10.19-37.60$ & 0.00 \\
\hline $\begin{array}{l}\text { Spoke with positive COVID-19 index case for } \\
\text { more than } 15 \text { mins few days before cating the } \\
\text { disease }\end{array}$ & Yes & 69 & 25 & 15.58 & $8.58-28.27$ & 0.00 \\
\hline $\begin{array}{l}\text { Individual did not use a face mask during all of } \\
\text { his contact episodes with the positive index case }\end{array}$ & Yes & 91 & 69 & 19.19 & $9.11-40.41$ & 0.00 \\
\hline Participating in gathering or social events & Yes & 73 & 19 & 25.75 & $13.48-49.17$ & 0.00 \\
\hline
\end{tabular}

positive symptomatic case was 5.67 times more among the PCR positive contacts as compare to PCR negative contacts $(\mathrm{p}=00.00$, C.I $=2.58-12.48)$, more over the odds for used the same vehicle after it was used by the COVID-19 index case was 19.58 times more among the PCR positive contacts as compare to PCR negative contacts $(p=00.00, C . I=10.19-37.60)$, also the odds for spoke with positive COVID-19 index case for more than 15 mins few days before catching the disease was 15.58 times more among the PCR positive contacts as compare to the PCR negative contacts $(\mathrm{p}=00.00$, C.I $=8.58$ - 28.27), similarly the odds for Individual did not use a face mask during all of his contact episodes with the positive index case was 19.19 times more among the PCR positive contacts as compare to PCR negative contacts ( $\mathrm{p}=00.00$, C.I $=9.11-40.41)$, lastly the odds for participating in a gathering or social events were 25.75 times more among 
the PCR positive contacts as compare to PCR negative contacts $(\mathrm{p}=00.00, \mathrm{C} . \mathrm{I}=$ 13.48 - 49.17).

\section{Discussion}

The major findings of this study are almost in line with the set hypothesis, this study is clearly showing that the odds of various COVID-19 infection prevention and Control (IPC) measures studied among COVID-19 PCR positive contacts (cases) and COVID-19 PCR negative contacts (controls) were found to be significant likewise the odds for knowingly and intentionally contacted with a COVID-19 positive case was 13.7 times more among the PCR positive contacts as compare to PCR negative contacts $(p=0.00$, C.I $=7.62-24.90)$, similarly the odds of being a family member of the index COVID-19 case was 7.07 times more among the PCR positive contacts as compare to the PCR negative contacts ( $\mathrm{p}=$ 0.00 , C.I $=3.25$ - 15.86), also the odds for knowingly and intentionally received an object handed over by a COVID-19 positive case was 6.64 times more among the PCR positive contacts as compare to PCR negative contacts $(\mathrm{p}=0.00$, C.I = $2.61-15.98)$, whereas the odds for touched the same surface/surfaces after it was touched by the index case was 6.15 times more among the PCR positive contact as compare to PCR negative contacts $(p=0.00$, C.I $=3.62-10.43)$, more over the odds for not doing regular hand washing was 22.24 times more among the PCR positive contacts as compare to the PCR negative contacts $(\mathrm{p}=00.00$, C.I $=11.79$ - 41.94), while the odds for knowingly and intentionally did not follow the government SOPs of social distancing during encounter with a positive symptomatic case was 5.58 times more among the PCR positive contacts as compare to the PCR negative contacts ( $\mathrm{p}=00.00$, C.I $=2.01-16.85$ ), also the odds for knowingly and intentionally did not follow the government SOPs of social distancing during sharing of bedroom and toilet with positive symptomatic case was 5.67 times more among the PCR positive contacts as compare to PCR negative contacts $(\mathrm{p}=00.00$, C.I $=2.58-12.48)$, more over the odds for used the same vehicle after it was used by the COVID-19 index case was 19.58 times more among the PCR positive contacts as compare to PCR negative contacts $(\mathrm{p}=00.00$, C.I = 10.19 - 37.60), also the odds for spoke with positive COVID-19 index case for more than $15 \mathrm{mins}$ few days before catching the disease was 15.58 times more among the PCR positive contacts as compare to the PCR negative contacts ( $\mathrm{p}=$ 00.00 , C.I $=8.58$ - 28.27), similarly the odds for individual did not use a face mask during all of his contact episodes with the positive index case was 19.19 times more among the PCR positive contacts as compare to PCR negative contacts $(\mathrm{p}=00.00$, C.I $=9.11-40.41)$, lastly the odds for participating in a gathering or social events were 25.75 times more among the PCR positive contacts as compare to PCR negative contacts $(\mathrm{p}=00.00$, C.I $=13.48-49.17)$.

In a similar study done by Hsiang, S. and the others [2] where they have assessed the effectiveness of various ongoing anti-contagion policies, similar to our study results they have also reported positive effectiveness of various anti-conta- 
gious policies it was observed by them if SOPs and IPC measures were properly implemented it slowed the average growth rate of infections by -0.252 per day $(\mathrm{SE}=0.045,164 \mathrm{p}<0.001)$ in China, $-0.248(\mathrm{SE}=0.089, \mathrm{p}<0.01)$ in South Korea, $-0.24(\mathrm{SE}=0.068, \mathrm{p}<0.001)$ in 165 Italy, $-0.355(\mathrm{SE}=0.063, \mathrm{p}<0.001)$ in Iran, $-0.123(\mathrm{SE}=0.019, \mathrm{p}<0.001)$ in France and $-0.084166(\mathrm{SE}=0.03, \mathrm{p}<$ $0.01)$ in the US [10].

Similarly, a study by Lai, S. and others have predicted the infection rates and quantified the impact of various Non-Pharmacological Interventions (NPI) among communities according their calculations without NPIs, their model predicted the number of cases of COVID-19 to increase rapidly across China, with a 51-fold (IQR 33 - 71) increase in Wuhan, a 92-fold (58 - 133) increase in other cities in Hubei province and a 125-fold (77 - 180) increase in other provinces by $29^{\text {th }}$ February 2020. However, the apparent effectiveness of different interventions varied. Nevertheless, if intercity travel restrictions had been implemented, cities and provinces outside of Wuhan would have not received more cases from Wuhan, and the affected geographical range would not have expanded to the remote western areas of China [13]. In general, they estimated that the early detection and isolation of cases quickly and substantially adopting IPC measure more infections were controlled like contact reduction and social distancing measures across the country. However, without the contact reduction intervention, in the longer term the epidemics would have increased exponentially across regions. Therefore, collective NPIs would bring about the strongest and most rapid effect on containment of the COVID-19 outbreak, with an interval of about one week between the introduction of NPIs and the peak of the epidemic [13]. The same effectiveness of Non pharmacological interventions like Infection Prevention and Controls (IPC) measures if properly adopted the COVID-19 transmission rate could be lowered.

Similarly, in another study by Flaxman, S. and the others showed that major Non-Pharmaceutical Interventions (NPI) and lockdowns in particular have had a large effect on reducing transmission in Europeans. Continued intervention should be considered to keep transmission of SARS-CoV-2 under control [14]. Lockdown also causes social distancing similar to our study, social distancing is proved to be effective against COVID-19 transmission by both the studies.

This study is different from other such studies because we have studied the effectiveness of COVID-19 Infection Prevention and Controls (IPC) measures among the contacts of an index case and have shown that the contacts who had positive COVID-19 PCR reports were poorly following the IPC measures.

\section{Conclusion \& Recommendation}

Being the first study of this kind in Pakistan, the major findings of this study show that the PCR positive contacts poorly adopted certain anti-COVID-19 IPC measures in their daily life hence got infected based on this evidence. It is highly recommended that the media of the health department of the government in 
Balochistan should inform the importance of these IPC measures to every individual as well as the necessity of the adoption of the measures in their daily life till the development and availability of the COVID-19 vaccine for everyone.

\section{Acknowledgements}

Thanks to our dear parents who always supported us through every thick and thin in life.

\section{Conflicts of Interest}

The authors declare no conflicts of interest regarding the publication of this paper.

\section{References}

[1] WHO (2020) WHO Coronavirus Disease (COVID-19) Dashboard. https://covid19.who.int

[2] Hsiang, S., Allen, D., Annan-Phan, S., Bell, K., Bolliger, I., Chong, T., Druckenmiller, H., Huang, L.Y., Hultgren, A., Krasovich, E., Lau, P., Lee, J., Rolf, E., Tseng, J. and Wu, T. (2020) The Effect of Large-Scale Anti-Contagion Policies on the COVID-19 Pandemic. Nature, 584, 262-267. https://doi.org/10.1038/s41586-020-2404-8

[3] Lai, S, Ruktanonchai, N.W., Zhou, L., Prosper, O., Luo, W., Floyd, J.R., Wesolowski, A., Santillana, M., Zhang, C., Du, X., Yu, H. and Tatem, A.J. (2020) Effect of Non-Pharmaceutical Interventions to Contain COVID-19 in China. Nature, 585, 410-413. https://doi.org/10.1038/s41586-020-2293-X

[4] Flaxman, S., Mishra, S., Gandy, A., Unwin, H.J.T., Mellan, T.A., Coupland, H., Whittaker, C., Zhu, H., Berah, T., Eaton, J.W., Monod, M., Ghani, A.C., Donnelly, C.A. Riley, S., Vollmer, M.A.C., Ferguson, N.M., Okell, L.C. and Bhatt, S. (2020) Estimating the Effects of Non-Pharmaceutical Interventions on COVID-19 in Europe. Nature, 584, 257-261. https://doi.org/10.1038/s41586-020-2405-7

[5] Arons, M.M., Hatfield, K.M., Reddy, S.C., et al. (2020) Presymptomatic SARS-CoV-2 Infections and Transmission in a Skilled Nursing Facility. The New England Journal of Medicine, 382, 2081-2090. https://doi.org/10.1056/NEJMoa2008457

[6] Gudbjartsson, D.F., Helgason, A., Jonsson, H., et al. (2020) Spread of SARS-CoV-2 in the Icelandic Population. The New England Journal of Medicine, 382, 2302-2315. https://doi.org/10.1056/NEJMoa2006100

[7] McMichael, T.M., Currie, D.W., Clark, S., et al. (2020) Epidemiology of Covid-19 in a Long-Term Care Facility in King County, Washington. The New England Journal of Medicine, 382, 2005-2011. https://doi.org/10.1056/NEJMoa2005412

[8] Hamner, L., Dubbel, P., Capron, I., et al. (2020) High SARS-CoV-2 Attack Rate following Exposure at a Choir Practice-Skagit County, Washington, March 2020. MMWR (Morbidity and Mortality Weekly Report), 69, 606-610. https://doi.org/10.15585/mmwr.mm6919e6

[9] Luo, L., Liu, D., Liao, X., et al. (2020) Contact Settings and Risk for Transmission in 3410 Close Contacts of Patients with COVID-19 in Guangzhou, China: A Prospective Cohort Study. Annals of International Medicine, 173, 879-887. https://doi.org/10.7326/M20-2671

[10] Yong, S.E.F., Anderson, D.E., Wei, W.E., et al. (2020) Connecting Clusters of COVID19: An Epidemiological and Serological Investigation. The Lancet Infectious Dis- 
eases, 20, 809-815. https://doi.org/10.1016/S1473-3099(20)30273-5

[11] Sun, Y., Koh, V., Marimuthu, K., et al. (2020) Epidemiological and Clinical Predictors of COVID-19. Clinical Infectious Diseases, 71: 786-792. https://doi.org/10.1093/cid/ciaa322

[12] Ng, Y., Li, Z., Chua, Y.X., et al. (2020) Evaluation of the Effectiveness of Surveillance and Containment Measures for the First 100 Patients with COVID-19 in Singapore-January 2-February 29, 2020. MMWR (Morbidity and Mortality Weekly Report), 69, 307-311. https://doi.org/10.15585/mmwr.mm6911e1

[13] WHO (2020) Coronavirus Disease (COVID-19) Advice for the Public. https://www.who.int/emergencies/diseases/novel-coronavirus-2019/advice-for-public

[14] Wei, W.E., Li, Z., Chiew, C.J., Yong, S.E., Toh, M.P. and Lee, V.J. (2020) Presymptomatic Transmission of SARS-CoV-2-Singapore, January 23-March 16, 2020. MMWR (Morbidity and Mortality Weekly Report), 69, 411-415.

https://doi.org/10.15585/mmwr.mm6914e1 